\title{
The Analgesic Effect of Ethanol Extract Soursop (Annona muricata L.) Leaves in Wistar Rats
}

\author{
Kuswinarti, ${ }^{1}$ Kendry Savira, ${ }^{2}$ Reno Rudiman ${ }^{3}$ \\ ${ }^{1}$ Department of Biomedical Sciences Faculty of Medicine Universitas Padjadjaran, Indonesia \\ ${ }^{2}$ Faculty of Medicine Universitas Padjadjaran, Indonesia, ${ }^{3}$ Departement of Surgery \\ Faculty of Medicine Universitas Padjadjaran/Dr. Hasan Sadikin General Hospital Bandung, \\ Indonesia
}

\section{Abstract}

Background: Pain is an emotional and sensory experience that is unpleasant and related to tissues damage. In the past, Soursop (Annona muricata L.) leaves have been believed to be able to relieve pain. This study aimed to explore the analgesic effect of soursop leaves and its effective dose in an animal model.

Methods: Wistar rats $(n=25)$ had been used in this experimental study, divided into 5 groups; consisting of a negative control group, experiment groups using extract soursop leaves with doses of $200 \mathrm{mg} / \mathrm{kgbw}$, $400 \mathrm{mg} / \mathrm{kgbw}$ and $600 \mathrm{mg} / \mathrm{kgbw}$, and natrium diclofenac as a positive control. One hour after treatment, all groups of rats were induced by carrageenan-lambda in the feet. The basal retraction of rats' legs was measured in $47^{\circ} \mathrm{C}$ water and repeated at two, four, and six hours. The data were analyzed using analysis of variance and Tukey's test.

Result: The dose of $200 \mathrm{mg} / \mathrm{kgbw}$ had no analgesic effect ( $\mathrm{p}>0.05$ ), while the dose of $600 \mathrm{mg} / \mathrm{kgbw}$ had the highest analgesic effect at 7.72 seconds on the 4 th hour of induction. On the $6^{\text {th }}$ hour, the dose of 400 $\mathrm{mg} / \mathrm{kgbw}$ had the highest analgesic effect at 3.58 seconds.

Conclusions: Extract soursop (Annona muricata L.) leaves in this study have been proven to have an analgesic effect.

Keywords: Analgesic. Annona muricata L., soursop leaves

\section{Introduction}

Annona muricata L. (Annonaceae), known as soursop plants, are commonly found in Central America to South America, including the North, Northeast and Southeast regions of Brazil. ${ }^{1,2}$ In Indonesia, especially West Java province, many soursop plants are cultivated in the area of Pelabuhan Ratu Sukabumi and Rajamandala Bandung. Traditionally, the soursop leaves can be used for headaches, insomnia, cystitis, liver problems, diabetes mellitus, sedative, hypotensive activity, analgesic, anti-inflammatory, and antidysenteric.,3 Moreover, the leaves have parasiticidal, anti-rheumatic and anti-neuralgic effects. ${ }^{1,2}$ Bioactive compounds of soursop leaves have been reported to be found such as acetogenins, alkaloids (isoquinoline, aporphine, protoberberine), tannin, coumarins, flavonoids, polyphenolic components, phytosterol ( $\beta$-sitosterol, stigmasterol), vitamins $\mathrm{B}, \mathrm{C}$, and $\mathrm{E} .^{4-6}$ Flavonoid is a strong inhibitor to lipid peroxidation, as a captor of reactive oxygen or nitrogen and also able to inhibit lipoxygenase and cyclooxygenase enzymes and as such, this compound can be used to reduce pain and thus serve as analgetic agent. ${ }^{7-9}$

Studies regarding soursop leaves as antiinflammation, anti-rheumatic, and antineuralgia supported by pharmacological and clinical validation are still scarce ${ }^{1}$, especially soursop leaves cultivated in West Java. This study aimed to explore the analgesic effect of the ethanol extract of soursop leaves from West Java, using an animal model.

\section{Methods}

This was an experimental study, conducted from May 2012 to January 2013, using Wistar rats, to explore whether soursop leaves extract had an analgesic effect. The

Correspondence: Kuswinarti, Departmen of Biomedical Sciences Faculty of Medicine Universitas Padjadjaran, Jalan Raya Bandung-Sumedang Km. 21, Jatinangor, Jawa Barat, Indonesia, Email: wiwinsumarlan@yahoo.com 
Table 1 Leg Retraction Time After Administration of Soursop Leaves (Annona muricata L.) Ethanol Extract

\begin{tabular}{lcccccccccc}
\hline & \multicolumn{3}{c}{ 2 hours } & \multicolumn{1}{c}{ 4 hours } & \multicolumn{3}{c}{ 6 hours } \\
\cline { 2 - 11 } & $\overline{\mathrm{X}}$ & \pm & $\mathrm{SD}$ & $\overline{\mathrm{X}}$ & \pm & $\mathrm{SD}$ & $\overline{\mathrm{X}}$ & \pm & SD \\
\hline Negative control & 1.35 & \pm & 0.27 & 1.61 & \pm & 0.48 & 1.30 & \pm & 0.27 \\
Dose 200mg/kgbw & 1.91 & \pm & 0.50 & 3.72 & \pm & 1.65 & 1.49 & \pm & 0.24 \\
Dose 400mg/kgbw & 2.39 & \pm & 0.61 & 4.86 & \pm & 1.65 & 3.58 & \pm & 1.49 \\
Dose 600mg/kgbw & 3.36 & \pm & 1.66 & 7.72 & \pm & 2.04 & 3.36 & \pm & 0.85 \\
Positive control & 3.08 & \pm & 1.06 & 3.73 & \pm & 1.03 & 2.02 & \pm & 0.57 \\
\hline
\end{tabular}

Note: $\overline{\mathrm{X}}=$ average of leg retraction time in seconds; $\mathrm{SD}=$ standard deviation. Natrium diclofenac was given for positive control.

hyperalgesia test applied was according to a modified Randall-Sellito. ${ }^{10-12}$ This study was performed in the Pharmacology Laboratory, Faculty of Medicine, Universitas Padjadjaran, and after ethical clearance, granted by the Health Research Ethic Committee Faculty of Medicine Universitas Padjadjaran. Inclusion criteria in this study were white male Wistar rats weighed at 180-220 grams, aged 2-3 months in healthy conditions and normal activity. Experimental rats were randomly assigned to groups 1 to 5 . Group 1 was given $2 \mathrm{~mL}$ carboxymethyl cellulose (CMC) per oral and served as a negative control group. Group 2 to 4 were given ethanol extract of soursop leaves per oral, with doses of 200, 400 , and $600 \mathrm{mg} / \mathrm{kgbw}$, respectively. Group 5 as a positive control group was given natrium diclofenac per oral with a dose of $4.5 \mathrm{mg} / \mathrm{kgbw}$. One hour after giving the experimental dose, carrageenan-lambda was given to the left foot to induce inflammation and pain. After two, four, and six hours of induction, respectively, measurement of left leg retraction time was examined in each group, by plunging their left leg to a water bath filled with $47^{\circ} \mathrm{C}$ water. The ankles of the rats were marked with waterproof tint as the marker of plunging. The length of the leg retraction time was limited to 15 seconds to avoid any thermal injuries.

Statistical analyses were conducted to compare the analgesic effect of different doses given and leg retraction time at two, four, and six hours after of induction, by using analysis of variance ( $\mathrm{F}$ test), followed by Tukey test.

\section{Results}

The leg retraction time from various doses of soursop leaves ethanol extract treatment

Table 2 Tukey Test on Leg Retraction Time 2 hours After Administration of Soursop Leaves (Annona muricata L.) Ethanol Extract

\begin{tabular}{|c|c|c|c|}
\hline Group (I) & Group (J) & $\frac{\text { Mean Difference }}{(\mathrm{I}-\mathrm{J})}$ & $\mathbf{p}$ \\
\hline \multirow[t]{4}{*}{ Control negative } & Dose $200 \mathrm{mg} / \mathrm{kgbw}$ & -0.564 & 0.073 \\
\hline & Dose $400 \mathrm{mg} / \mathrm{kgbw}$ & $-1.046^{*}$ & $0.003^{*}$ \\
\hline & Dose $600 \mathrm{mg} / \mathrm{kgbw}$ & $-2.016^{*}$ & $0.000^{*}$ \\
\hline & natrium diclofenac & $-1.736^{*}$ & $0.000^{*}$ \\
\hline \multirow[t]{3}{*}{ Dose $200 \mathrm{mg} / \mathrm{kgbw}$} & Dose $400 \mathrm{mg} / \mathrm{kgbw}$ & -0.482 & 0.623 \\
\hline & Dose $600 \mathrm{mg} / \mathrm{kgbw}$ & -1.452 & 0.104 \\
\hline & natrium diclofenac & -1.172 & 0.134 \\
\hline \multirow[t]{2}{*}{ Dose $400 \mathrm{mg} / \mathrm{kgbw}$} & Dose $600 \mathrm{mg} / \mathrm{kgbw}$ & -0.970 & 0.751 \\
\hline & natrium diclofenac & -0.690 & 0.822 \\
\hline Dose $600 \mathrm{mg} / \mathrm{kgbw}$ & natrium diclofenac & 0.280 & 1.000 \\
\hline
\end{tabular}

Note: *significancy was set on $\mathrm{p}<0.05$ 
Table 3 Tukey Test on Leg Retraction Time 4 hours After Administration of Soursop Leaves (Annona muricata L.) Ethanol Extract

\begin{tabular}{llcc}
\hline \multirow{2}{*}{ Group (I) } & Group (J) & Mean Difference & p \\
\cline { 3 - 4 } & & (I-J) & 0.199 \\
\hline Control negative & Dose 200mg/kgbw & -2.110 & $0.018^{*}$ \\
& Dose 400mg/kgbw & -3.252 & $0.000^{*}$ \\
& Dose 600mg/kgbw & -6.112 & 0.193 \\
& natrium diclofenac & -2.128 & 0.739 \\
Dose 200mg/kgbw & Dose 400mg/kgbw & -1.142 & $0.003^{*}$ \\
& Dose 600mg/kgbw & -4.002 & 1.000 \\
Dose 400mg/kgbw & natrium diclofenac & -0.018 & $0.043^{*}$ \\
Dose 600mg/kgbw & Dose 600mg/kgbw & -2.860 & 0.749 \\
\hline
\end{tabular}

Note: *significancy was set on $\mathrm{p}<0.05$

per oral to Wistar Rats after 2 hours of carrageenan-lambda induction were as followed; there was a significant increase of leg retraction time with doses of 200,400 , and $600 \mathrm{mg} / \mathrm{kgbw}$ compared to negative control. This study indicated that the experiment doses shown an analgesic effect on the increase of leg retraction time. The soursop leaves ethanol extract dose of $600 \mathrm{mg} / \mathrm{kgbw}$ had an average analgesic effect of the highest at 7.72 seconds on the 4 th hour of induction. The dose of $600 \mathrm{mg} / \mathrm{kgbw}$ had reached the maximum time equivalent to the treatment induced by natrium diclofenac, as a positive control. The result of leg retraction time after 2, 4, 6 hours of carrageenan-lambda induction with various doses of soursop leaves was shown in Table 1.

In summary, the leg retraction time from various doses of soursop leaves ethanol extract treatment per oral to Wistar Rats after 4 and 6 hours of carrageenan-lambda induction were as followed; there was a significant increase of leg retraction time with doses of 200, 400, and $600 \mathrm{mg} / \mathrm{kgbw}$ compared to negative control (Table 2, 3, 4). As for the induction of carrageenan-lambda after 4 hours, there was a maximum leg retraction time comparable to positive control already with the dose of 200

Table 4 Tukey Test on Leg Retraction Time 6 hours After Administration of Soursop Leaves (Annona muricata L.) Ethanol Extract

\begin{tabular}{llcc}
\hline \multirow{2}{*}{ Group (I) } & Group (J) & Mean Difference & p \\
\cline { 3 - 4 } & Dose $200 \mathrm{mg} / \mathrm{kgbw}$ & -0.192 & 0.844 \\
\hline Control negative & Dose $400 \mathrm{mg} / \mathrm{kgbw}$ & -2.276 & $0.000^{*}$ \\
& Dose 600mg/kgbw & -2.064 & $0.000^{*}$ \\
& natrium diclofenac & -0.716 & 0.101 \\
Dose $200 \mathrm{mg} / \mathrm{kgbw}$ & Dose 400mg/kgbw & -2.084 & $0.003^{*}$ \\
& Dose 600mg/kgbw & -1.872 & $0.003^{*}$ \\
Dose 400mg/kgbw & natrium diclofenac & -0.524 & 0.502 \\
Dose 600mg/kgbw & Dose 600mg/kgbw & 0.212 & 1.000 \\
\hline
\end{tabular}

Note: *significancy was set on $\mathrm{p}<0.05$ 
$\mathrm{mg} / \mathrm{kgbw}$ that was further increased with the dose of 400 , and $600 \mathrm{mg} / \mathrm{kgbw}$; whereas for induction of carrageenan-lambda after 6 hours, the dose of 400 and $600 \mathrm{mg} / \mathrm{kgbw}$ showed comparable leg retraction time $(3.58 \mathrm{~s}$ and $3.36 \mathrm{~s}$, respectively) and showed no significant difference to positive controls (2.02s).

\section{Discussion}

Annona muricata produced antinociception action of activity in both neurogenic and inflammatory phases. Metabolites of arachidonic acid (called eicosanoids) are involved in the inflammation process. ${ }^{1}$ In this study, Carrageenan-lambda has been used. Carrageenan-lambda is a red sea seaweed extract that is often used to induce pain in the laboratory setting for experimental study. 2,13 This study shown that soursop leaf extract given an hour before administration of carrageenan-lambda induction has a comparable analgetic effect with natrium diclofenac. Natrium diclofenac has been proven to have an analgesic effect and in this study, it is used as a positive control. The metabolites are produced via cyclooxygenase and lipoxygenase when the cell is activated by mechanical trauma, cytokines, growth factors or other stimuli. It has been proposed that the mechanism of antinociception may be caused by inhibition of cyclooxygenase (COX) and lipoxygenases (LOX) and other inflammatory mediators such as flavonoids, present in the plant extract. ${ }^{1,2}$ Flavonoids contained in soursop leaves are strong inhibitors to lipid peroxidation, and serve as a captor of reactive oxygen or nitrogen and also able to inhibit cyclooxygenase enzymes thereby reducing the biosynthesis of prostaglandins which are pain mediators and as such this compound can be used to reduce pain (analgesic). ${ }^{1,14}$ Diclofenac is a phenyl acetic derivate that is relatively nonselective as a COX inhibitor. This drug has analgesic, antipyretic and anti-inflammatory effects by inhibiting prostaglandin synthesis.

The inhibition of the synthesis of proinflammatory prostaglandins is one of such therapeutic targets to which some of the potent analgesic and anti-inflammatory agents. ${ }^{15}$ The analgesic effect can be seen by lengthened time of foot withdrawal. Hyperalgesia by the inflammatory process because of an increased sensitivity to pain receptors and a decrease in the pain threshold. Our study has shown that soursop leaf extract has an analgesic effect compared to the negative control group, and comparable to the positive control group Diclofenac. Interestingly, the length of induction with carrageenan-lambda has shown that there is an optimum effect of the inflammatory effect of carrageenan-lambda (i.e. 4 hours) and soursop leaves extract might be useful in lower doses. In this study, the strongest analgesic effect occurred at the $4^{\text {th }}$ hour of induction probably the inhibitory effect on pain mediators was the most optimal, while at the $6^{\text {th }}$ hour the inhibitory effect was reduced and caused no different dosage of $400 \mathrm{mg} / \mathrm{kgbw}$ and $600 \mathrm{mg} / \mathrm{kgbw}$ soursop leaf extract.

This study has hampered some limitations. The result of leg retraction time varies greatly with a high standard deviation. Since this experiment used an animal model, a minimal number of rats had been used. Further study is needed to confirm the true effect of soursop leaves as an analgesic agent.

Soursop (Annona muricata L.) leaves ethanol extract has been proven to have an analgesic effect on Wistar rats induced by carrageenanlambda. Soursop (Annona muricata L.) extract may be useful in human, therefore, further in vivo study is needed.

\section{References}

1. De Sousa OV, Vieira GDV, De Pinho JDJR., Yamamoto CH, Alves MS. Antinociceptive and anti-inflammatory activities of the ethanol Extract of Annonamuricata L. leaves in animal models. Int J Mol Sci. 2010;11(5): 2067-78

2. Moghadamtousi SZ, Fadaeinasab M, Nikzad S, Mohan G, Ali HM, Kadir HA. Annona muricata (Annonaceae): A review of its traditional uses, isolated acetogenins, and biological activities.Int J Mol Sci. 2015;16(7):15625-58

3. Coria-tellez AV, Montalvo-Gonzalez E, Yahia EM, Obledo-Vazquez EN. Annonamuricata: A Comprehensive Review on its traditional medicinal uses, phytochemicals, pharmacological activities, mechanisms of action and toxicity. Arab J Chem 2018;11(5):662-91

4. Salempa P. Uji bio aktivitas senyawa metabolit sekunder ekstrak kloroform kulit batang sirsak (Annonamuricata Linn.) Jurnal Bionature. 2016;17(1):37-40

5. Wurdianing I, Nugraheni SA, Rahfiludin Z. Efek ekstrak daun sirsak (Annonamuricara Linn.) terhadap profil lipid putih jantan (Rattus Norvegicus). Jurnal Gizi Indonesia. 2014:3(1):7-12

6. Suharyadi A, SukoharA, Muhartono. 
Pengaruh pemberian ekstrak etanol daun sirsak terhadap gambaran histopatologi ginjal tikus yang diinduksi DMBA. Medical Jurnal of Lampung University. 2014;3(4):27-34.

7. Simanjuntak K. Peran antioksidan flavonoid dalam meningkatkan kesehatan. Bina Widya. 2012;23(3):135-40

8. Syamsul ES, Andani F, Soemarie YB. Analgesic activity study of ethanolic extract of Callicarpalongifolia Lamk in mice. Trad Med J. 2016;21(2):99-103

9. Christiana I, Evacuasiany E, Hidayat M. The analgetic effect of kayu rapat bark infusion (Parameria laervigata (Juss.) Moldenke) on male mice treated with thermal induction. Jurnal Medika Planta. 2012;2(1):69-76

10. Satos-Nogueira E, Redondo Castro E, Mancuso R, Navarro X. Randall-Sellito test: a new approach for the detection of neuropathic pain after spinal cord injury. J Neurotrauma. 2012;29(5):898-904

11. Fajrin FA, Nurrochmad A, Nugroho AE, Susilowati R. Optimization of mice model of painful diabetic neuropathy (PDN). J Med Sci. 2017;49(3):97-105

12. Parkar N, Addepalli V. Effect of Nobiletin on diabetic neuropathy in experimental rats. Austin J Pharmacol Ther 2014;2(5):1028.

13. Mariappan G, Saha BP, Sutharson L, Singh A, Garg S, Pandey L, et al. Analgesic, antiinflammatory, antipyretic and toxicological evaluation of some newer 3-methyl pyrazolone derivates. Saudi Pharm J. 2011;19(2):115-22

14. Arifin H, Alwi TI, Aisyahharma O, Juwita DA. Kajian efek analgetik dan toksisitas subakut dari ekstrak etanol daun kitolod (Isotomalongiflora L.) pada mencit putih jantan. Jurnal Sains Farmasi \& Klinik. 2018:5(2):112-8

15. Negm AA, Furst DE. Nonsteroidal antiinflammatory drugs, disease-modifying antirheumatic Drugs, nonopioid analgesics \& drugs Used in Gout. In: Katzung BG, editor. Basic and clinical pharmacology. 14th Ed. Singapore: McGraw-Hill; 2017: p. 647. 